Matgorzata RęKOSIEWicz

ORCID 0000-0002-3950-0649

Uniwersytet im. Adama Mickiewicza

$w$ Poznaniu

\title{
CZY ORIENTACJE ŻYCIOWE STUDENTÓW MEDIUJĄ RELACJĘ MIĘDZY SUMIENNOŚCIĄ JAKO CECHĄ OSOBOWOŚCI A OSIĄGNIĘCIAMI AKADEMICKIMI?
}

\begin{abstract}
AвSTRACT. Rękosiewicz Małgorzata, Czy orientacje życiowe studentów mediują relację między sumiennościq jako cecha osobowości a osiagnięciami akademickimi? [Do Students' Life Orientations Mediate the Relationship Between Conscientiousness as a Personality Feature and Educational Achievement?]. Studia Edukacyjne nr 57, 2020, Poznań 2020, pp. 267-282. Adam Mickiewicz University Press. ISSN 12336688. DOI: $10.14746 /$ se.2020.57.19

Conscientiousness as a personality trait has been recognized as a predictor of students' academic achievements in numerous empirical studies. The aim of the study was to determine the role of life orientations, moratorium and transitive orientation, in the relationship between conscientiousness and academic achievement. The study was conducted using Social Participation Questionnaire and the NEO-FFI Personality Inventory among 111 full-time students aged 20-25. Conscientiousness turned out to be a predictor of both academic achievement and life orientation, but these orientations did not mediate the relationship between conscientiousness and academic achievement.
\end{abstract}

Key words: life orientations, personality, social participation, educational achievement prediction, student

W literaturze udokumentowano liczne pozaintelektualne korelaty i predyktory osiągnięć edukacyjnych na każdym szczeblu edukacji, w tym wśród studentów ${ }^{1}$. Cechy osobowości, a w szczególności cecha z zakresu tak zwanej Wielkiej Piątki - sumienność, została rozpoznana jako silny lub przynajmniej umiarkowanie silny predyktor wyników edukacyjnych uczniów i studen-

${ }^{1}$ M. Richardson, C. Abraham, R. Bond, Psychological correlates of university students' academic performance: a systematic review and meta-analysis, Psychological Bulletin, 2012, 138(2), s. 353. 
tów². Obecnie podejmuje się poszukiwania wyjaśnień mechanizmów oddziaływania cech osobowości na wyniki edukacyjne.

Przeprowadzone badanie opierało się na hipotezie o mediacyjnej roli orientacji życiowych (w ujęciu Heinza Reindersa ${ }^{3}$ ) w trakcie wkraczania $\mathrm{w}$ dorosłość $\mathrm{w}$ relacji sumienność - wyniki edukacyjne. Zgodnie z ujęciem teoretycznym orientacji życiowych, realizowanie zadań stawianych $\mathrm{w}$ toku edukacji stanowi wypełnianie zinternalizowanych oczekiwań otoczenia społecznego i podjętego zadania rozwojowego, jakim jest przygotowanie do wkroczenia $w$ dorosłość. Hipotetycznie, szczególnie strategia udziału w życiu społecznym studentów oraz ich postawy wobec okresu studiowania jako czasu, w którym należy przygotować się do tranzycji do dorosłości (orientacja tranzytywna), a nie jedynie w którym należy czerpać $\mathrm{z}$ danych szans aktualizacji potencjałów rozwojowych (orientacja moratoryjna) mediują relację między sumiennością a wynikami edukacyjnymi, wspierając jej oddziaływanie.

\section{Problem}

Studenci znajdują się na etapie rozwojowym wkraczania $\mathrm{w}$ dorosłość, określanym jako wyłaniająca się dorosłość ${ }^{4}$. Uczenie się odbywa się w sposób "dorosły”, to jest bez nadzoru nauczyciela, typowego dla wcześniejszych etapów rozwojowych, z mniejszą kontrolą rodzicielską i większą odpowiedzialnością za przebieg własnego procesu uczenia się. Realizowanie zadań akademickich stanowi $\mathrm{w}$ tym okresie wypełnianie zinternalizowanych oczekiwań i wymagań otoczenia społecznego, jak również stanowi odniesienie do podjętego zadania rozwojowego, jakim jest przygotowanie do wkroczenia w dorosłość - studiowanie ma przygotować do samodzielnego dorosłego życia w obszarze zawodowym.

${ }^{2}$ M.C. O'Connor, S.V. Paunonen, Big Five personality predictors of post-secondary academic performance, Personality and Individual Differences, 2007, 43(5); A.E. Poropat, A meta-analysis of the five-factor model of personality and academic performance, Psychological Bulletin, 2009, 135(2), s. 971-990; tenże, The Eysenckian personality factors and their correlations with academic performance, British Journal of Educational Psychology, 2011, 81(1), s. 41-58; tenże, A meta-analysis of adult-rated child personality and academic performance in primary education, British Journal of Educational Psychology, 2014, 84(2), s. 239-252; S. Trapmann i in., Meta-analysis of the relationship between the Big Five and academic success at university, Zeitschrift für Psychologie/Journal of Psychology, 2007, 215(2), s. 132-151.

${ }^{3}$ H. Reinders, Jugendtypen zwischen Bildung und Freizeit. Theoretische Präzisierung und empirische Prüfung einer differenziellen Theorie der Adoleszenz, Münster - New York - München - Berlin 2006.

${ }^{4}$ J.J. Arnett, Emerging adulthood. A theory of development from the late teens through the twenties, American Psychologist, 2000, 55, s. 469-480. 
Osiągnięcia bądź wyniki edukacyjne w badaniach empirycznych mierzy się za pomocą "obiektywnych" wskaźników - ocen z przedmiotów lub za wybrane zadania edukacyjne, liczby punktów uzyskanych na danym egzaminie czy kursie, lub wskaźników „subiektywnych”, na przykład pod postacią osobistej satysfakcji z własnych ocen, wzrastającej wiedzy i umiejętności. Analizie empirycznej wielokrotnie poddawano poziom inteligencji i jej oddziaływania na obiektywne wyniki edukacyjne. Inteligencja wyjaśnia jednak tylko część wariancji osiągnięć i nie może być traktowana jako wyłączny predyktor osiągnięć edukacyjnych - ani u studentów, ani u młodszych uczniów. Wśród pozaintelektualnych korelatów i predyktorów osiągnięć edukacyjnych na każdym szczeblu edukacji wymienia się między innymi czynniki motywacyjne, takie jak: umiejscowienie kontroli, wymiar optymizm - pesymizm, samoocena, poczucie własnej skuteczności, motywacja do uczenia się, czy zorientowanie na cel. Osobną grupę stanowią podejście i postawy wobec uczenia się, a także pewne wpływy kontekstualne, jak integracja społeczna i akademicka, wsparcie społeczne i stres (w tym stres akademicki). Zweryfikowano także efektywność samoregulacyjnych strategii uczenia się, takich jak: powtórki, elaboracja, zarządzanie czasem, czy uczenie się z rówieśnikami. Odrębną grupę stanowią cechy osobowości badane w ramach teorii tak zwanej Wielkiej Piątki, a także perfekcjonizm, prokrastynacja i inteligencja emocjonalna ${ }^{5}$.

Cechy osobowości wydają się przydatnymi predyktorami osiągnięć edukacyjnych na najwyższych szczeblach kształcenia, gdzie maleje wariancja zdolności poznawczych. W związku z selekcją kandydatów na studia (przynajmniej studia stacjonarne) wariancja ta jest dużo mniejsza (poziom przeciętnej i wysokiej inteligencji) niż na poziomie szkoły podstawowej (w której może się wahać od poziomu z pogranicza upośledzenia do wysokich wartości) ${ }^{6}$. Na wyższym szczeblu edukacji wydaje się, że wyniki edukacyjne mogą, w większej mierze niż od inteligencji, zależeć od cech osobowości.

Osobowość można najszerzej zdefiniować jako całkowitą sumę charakterystyk behawioralnych i psychicznych wyróżniających daną jednostkę. Cechy, inaczej dyspozycje, to różnice indywidualne $\mathrm{w}$ zachowaniach, myślach i uczuciach, które są czasowo oraz sytuacyjnie spójne i stałe oraz wyznaczają typowy wzorzec zachowania jednostki ${ }^{8}$. Dlaczego osobowość ma wpływać na osiągnięcia edukacyjne? Wskazuje się, że wyniki edukacyjne i akademickie

${ }^{5}$ M. Richardson, C. Abraham, R. Bond, Psychological correlates of university students' academic performance, s. 353.

${ }^{6}$ Por. H.J. Eysenck (red.), A model for intelligence, Springer Science \& Business Media, 2012.

7 A.M. Colman, Stownik psychologii, Warszawa 2009, s. 481.

${ }^{8}$ D.P. McAdams, J.L. Pals, A new Big Five: Fundamental principles for an integrative science of personality, American Psychologist, 2006, 61(3), s. 204-217. 
są odzwierciedleniem: (1) zdolności (ang. capacity), to jest posiadanej wiedzy, umiejętności, ale też inteligencji; (2) możliwości (ang. opportunity), to jest statusu społeczno-ekonomicznego ucznia i studenta (co przekłada się np. na możliwości zapewnienia przez rodziców dziecku warunków do nauki), szerszych ograniczeń i zasobów środowiskowych; (3) chęci (ang. willingness), a więc motywacji, norm kulturowych dotyczących uczenia się, a także - osobowości. Po pierwsze więc, zmienne osobowościowe stanowią komponent chęci jednostki do działania. Po drugie, zmienne osobowościowe stanowią predyktory zachowań cenionych społecznie, a do takich, w naszej kulturze, należą czynione przez uczniów i studentów starania o jak najlepsze wyniki edukacyjne9.

W ramach teorii Wielkiej Piątki opisano następujące cechy osobowości ${ }^{10}$ :

- otwartość na doświadczenie (wymiar: niska - wysoka): to tendencja do poszukiwania i pozytywnego wartościowania doświadczeń życiowych, tolerancja wobec nowości i ciekawość poznawcza (składniki: wyobraźnia, estetyka, uczucia, działania, idee, wartości);

- sumienność (wymiar: niska - wysoka): to stopień zorganizowania, wytrwałości i motywacji w działaniach zorientowanych na cel (składniki: kompetencja, skłonność do utrzymywania porządku, obowiązkowość, dążenie do osiągnięć, samodyscyplina, rozwaga);

- ekstrawersja (wymiar: ekstrawersja - introwersja): to jakość i liczba interakcji społecznych, poziom aktywności, energii i zdolność do odczuwania pozytywnych emocji (składniki: towarzyskość, serdeczność, asertywność, aktywność, poszukiwanie doznań, emocjonalność w zakresie pozytywnych emocji);

- ugodowość (wymiar: niska - wysoka): to pozytywne/negatywne nastawienie do innych ludzi; orientacja interpersonalna altruistyczna/antagonistyczna (składniki: zaufanie, prostolinijność, altruizm, ustępliwość, skromność, skłonność do rozczulania się);

- neurotyczność (wymiar: przystosowanie emocjonalne - niezrównoważenie emocjonalne): to podatność na doświadczanie negatywnych emocji (składniki: lęk, agresywna wrogość, depresyjność, impulsywność, nadwrażliwość, nadmierny samokrytycyzm).

Badania nad możliwością przewidywania osiągnięć edukacyjnych i akademickich na podstawie nasilenia powyższych cech osobowości są już tak liczne, że możliwe było przeprowadzenie kilku metaanaliz badań tego zjawiska (tab. 1). Najsilniejszym predyktorem okazuje się sumienność. Jej pozytywny wpływ ujawnia się na wszystkich poziomach kształcenia i niezależnie od formy sprawdzania wiedzy. Wchodzące w skład osobowości komponen-

${ }^{9}$ A.E. Poropat, A meta-analysis of the five-factor model of personality, s. 322.

${ }_{10}$ P.T. Costa, R.R. McCrae, Normal personality assessment in clinical practice: The NEO Personality Inventory, Psychological Assessment, 1992, 4(1), s. 5-13. 
ty, takie jak skłonność do porządku, obowiązkowość, samodyscyplina, czy dążenie do osiągnięć mogą tłumaczyć, dlaczego zachodzi taka zależność. Osobom ambitnym, zorganizowanym i dążącym do osiągnięć, to znaczy posiadającym silną motywację - osiągnięcia, a także wytrwałym w pokonywaniu trudności łatwiej będzie uzyskiwać lepsze wyniki akademickie.

Tabela 1

Wyniki metaanaliz - cechy osobowości jako predyktory osiągnięć edukacyjnych i akademickich

\begin{tabular}{|l|c|c|c|c|c|c|}
\hline \multicolumn{1}{|c|}{$\begin{array}{c}\text { Cecha } \\
\text { osobowo- } \\
\text { ści }\end{array}$} & $\begin{array}{c}\text { O'Connor } \\
\text { i Pauno- } \\
\text { nen, 2007 }\end{array}$ & $\begin{array}{c}\text { Poropat, } \\
2009\end{array}$ & $\begin{array}{c}\text { Poropat, } \\
2011\end{array}$ & $\begin{array}{c}\text { Poropat, } \\
2014\end{array}$ & $\begin{array}{c}\text { Richard- } \\
\text { son, } \\
\text { Abraham } \\
\text { i Bond, } \\
2012\end{array}$ & $\begin{array}{c}\text { Trapman, } \\
\text { Hell, } \\
\text { Hirn } \\
\text { i Schuler, } \\
2007\end{array}$ \\
\hline $\begin{array}{l}\text { Neuro- } \\
\text { tyczność }\end{array}$ & 0 & - umiark. & - umiark. & - słaby & 0 & 0 \\
\hline $\begin{array}{l}\text { Otwar- } \\
\text { tość na } \\
\text { doświad- } \\
\text { czenie }\end{array}$ & 0 & + umiark. & - & $\begin{array}{c}\text { + umiark. } \\
\text { / silny }\end{array}$ & 0 & 0 \\
\hline $\begin{array}{l}\text { Ugodo- } \\
\text { wość }\end{array}$ & 0 & + umiark. & - & + słaby & 0 & 0 \\
\hline $\begin{array}{l}\text { Sumien- } \\
\text { ność }\end{array}$ & + silny & - & - & + silny & + silny & + silny \\
\hline $\begin{array}{l}\text { Ekstra- } \\
\text { wersja }\end{array}$ & 0 & + umiark. & + słaby & + słaby & 0 & 0 \\
\hline
\end{tabular}

0: brak zależności między cechą osobowości a osiągnięciami; --: brak badania zależności; +/-: kierunek zależności.

Rola pozostałych czterech cech osobowości jest niejednoznaczna, wyniki w ich zakresie są rozbieżne. Neurotyczność, jeśli stanowi predyktor osiągnięć, to jej wpływ jest negatywny, to jest - im wyższy poziom neurotyczności, tym słabsze osiągnięcia. Hipotetyczne wyjaśnienie może odnosić się do wysokiego poziomu lęku osób silnie neurotycznych, który może przekładać się na obniżenie poziomu wykonania zadania i/lub zmniejszenie motywacji ${ }^{11}$. Co ciekawe, płeć stanowi moderator w tej relacji - wykazano, że stabilność emocjonalna (niska neurotyczność) u mężczyzn (ale nie u kobiet) wiązała się z lepszymi osiągnięciami edukacyjnymi ${ }^{12}$.

11 R. Pekrun i in., Beyond test anxiety: Development and validation of the Test Emotions Questionnaire (TEQ), Anxiety, Stress and Coping, 2004, 17(3), s. 287-316.

12 N.T. Nguyen, L.C. Allen, K. Fraccastoro, Personality predicts academic performance: Exploring the moderating role of gender, Journal of Higher Education Policy and Management, 2005, 27(1), s. 105-117. 
Otwartość na doświadczenie, ugodowość i ekstrawersja, jeśli stanowią predyktory osiągnięć akademickich, to kierunek zależności jest pozytywny, to jest - im wyższy poziom cechy, tym lepsze osiągnięcia. Wyjaśnienia wpływu otwartości na doświadczenia upatruje się w jej korelacji z inteligencją skrystalizowaną, dobrą zdolnością radzenia sobie z nowym materiałem, „otwartością" na nową wiedzę ${ }^{13}$. Rolę ugodowości tłumaczy się tendencją do regularnego uczęszczania na zajęcia i współpracą z nauczycielami, natomiast rolę ekstrawersji - wysokim poziomem aktywności i zapotrzebowaniem na stymulację. $Z$ drugiej strony, w odniesieniu do każdej z tych trzech cech nietrudno wyobrazić sobie współwystępujące z nimi potrzeby i zachowania utrudniające realizowanie obowiązków studenckich, jak - bogate życie towarzyskie czy duża aktywność poza uczelnią u osób otwartych na doświadczenia, ustępliwość wobec propozycji pozauczelnianych u osób ugodowych, tendencja do aktywności towarzyskiej zamiast uczenia się u ekstrawertyków ${ }^{14}$.

O ile rola sumienności w predykcji osiągnięć edukacyjnych na każdym szczeblu edukacji jest niepodważalna, o tyle wiedza o mechanizmach tego zjawiska - ograniczona. Jak dotąd, dowiedziono, że poczucie własnej skuteczności jest mediatorem w relacji między samodyscypliną (komponent sumienności) a osiągnięciami akademickimi ${ }^{15}$. Mediatorami relacji sumienność - osiągnięcia akademickie są przystosowanie akademickie ${ }^{16}$ i podejście do uczenia się, w którym celem jest uczenie się samo w sobie lub cel stanowią dokonania ${ }^{17}$. Być może, w związku z tym, że studiowanie stanowi w pewien sposób realizowanie zadania rozwojowego przygotowania do dorosłości, można poszukiwać pośredniczącej roli podejścia studentów do samorozwoju w relacji sumienność - osiągnięcia akademickie.

Partycypacja społeczna w ujęciu Reindersa i innych ${ }^{18}$ definiowana jest jako strategia udziału w życiu społecznym młodzieży i osób wkraczających w do-

${ }^{13}$ Y.J. Vermetten, H.G. Lodewijks, J.D. Vermunt, The Role of Personality Traits and Goal Orientations in Strategy Use, Contemporary Educational Psychology, 2001, 26(2), s. 149-170.

${ }_{14}$ T. Bidjerano, D.Y. Dai, The relationship between the big-five model of personality and self-regulated learning strategies, Learning and Individual Differences, 2007, 17(1), s. 69-81.

${ }^{15}$ S. Guntern, H. Korpershoek, G. van der Werf, Benefits of personality characteristics and self-efficacy in the perceived academic achievement of medical students, Educational Psychology, 2017, 37(6), s. 733-744.

${ }^{16}$ H.N. Perera, P. McIlveen, M.E. Oliver, The mediating roles of coping and adjustment in the relationship between personality and academic achievement, British Journal of Educational Psychology, 2015, 85(3), s. 440-457.

17 I. Sorić, Z. Penezić, I. Burić, The Big Five personality traits, goal orientations, and academic achievement, Learning and Individual Differences, 2017, 54, s. 126-134.

${ }^{18} \mathrm{H}$. Reinders, Jugendtypen zwischen Bildung und Freizeit; H. Reinders i in., Typologische Entwicklungswege Jugendlicher. Die horizontale Dimension sozialräumlicher Entfaltung, [w:] Zukunftsperspektiven Jugendlicher. Wirtschaftliche und soziale Entwicklungen als Herausforderung und Bedrohung für die Lebensplanung, red. J. Mansel, W. Schweins, M. Ulbrich-Herrmann, München 2001, 
rosłość oraz ich postawa wobec młodości. Partycypacja wyraża się w dwóch wymiarach, inaczej w orientacjach życiowych. Pierwsza z nich to orientacja tranzytywna (OT - orientacja na rozwój lub na przejście do dorosłości). Obejmuje postawy wobec działań oraz podejmowanie działań, których skutki będą widoczne w dorosłości, podejmowanie nowych zadań rozwojowych i nabywanie kompetencji do podjęcia nowych ról społecznych. Orientacja tranzytywna jest wyznaczana społecznymi oczekiwaniami i wymaganiami ze strony rodziców, nauczycieli, innych znaczących dorosłych lub bardziej doświadczonych kolegów. Odnosi się do podejmowania zadań rozwojowych według Roberta Havighursta ${ }^{19}$. Wykazano, że orientacja tranzytywna wiąże się z subiektywnym wskaźnikiem dorosłości - tożsamością osobistą ${ }^{20}$. Im wyższy poziom orientacji tranzytywnej, tym wyższe natężenie eksploracji wszerz, eksploracji w głąb, podejmowania zobowiązania i identyfikacji ze zobowiązaniem w ujęciu Koena Luyckxa i innych ${ }^{21}$, to jest wymiarów, których wysokie natężenie cechuje osoby o statusie tożsamości osiągniętej.

Druga orientacja - moratoryjna (OM - orientacja na teraźniejsze możliwości rozwojowe) to postawy wobec działań i podejmowanie działań, których cele ani gratyfikacje nie są odroczone w czasie, jest to wartość aktywności samej w sobie. Możliwości rozwojowe związane z orientacją moratoryjną są mniej ustrukturalizowane niż zadania rozwojowe z orientacji tranzytywnej. Głównym czynnikiem rozwojowym są tutaj rówieśnicy.

Referowane badanie opierało się na własnej hipotezie o mediacyjnej roli orientacji życiowych w relacji sumienność - osiągnięcia akademickie (por. ryc. 1). Jeśli sumienność wiąże się z lepszymi wynikami akademickimi poprzez swoje powiązania z ambicją, zorientowaniem na osiągnięcia i wytrwałością w pokonywaniu trudności w uczeniu się, to wydaje się, że orientacja tranzytywna będzie wzmacniać tę zależność. Jednym z argumentów może być pozytywna postawa wobec uczenia się i nauczycieli osób o wysokiej orientacji tranzytywnej ${ }^{22}$. Ponadto, uczenie się jest traktowane przez osoby silnie zorientowane tranzytywnie jako możliwość zdobycia wiedzy i umiejętności potrzebnych w dorosłości. Osoby o silnej orientacji tranzytywnej cechują się wysokim zaufaniem do siebie, wiarą w swoje możliwości i poczuciem pew-

\footnotetext{
s. 200-216; H. Reinders, P. Butz, Entwicklungswege Jugendlicher zwischen Transition und Moratorium, Zeitschrift für Pädagogik, 2001, 47, s. 913-928.

19 R.J. Havighurst, Developmental tasks and education, New York, 1981.

${ }^{20} \mathrm{M}$. Rękosiewicz, Type of social participation and identity formation in adolescence and emerging adulthood, Polish Psychological Bulletin, 2013, 44, s. 277-287; taże, Społeczny kontekst kształtowania się tożsamości osób z niepetnosprawnościa intelektualna w okresie późnej adolescencji i wyłaniajaccej się dorostości, rozprawa doktorska, 2016.

${ }^{21} \mathrm{~K}$. Luyckx i in., Capturing ruminative exploration: extending the four-dimensional model of identity formation in late adolescence, Journal of Research in Personality, 2008, 42, s. 58-82.

${ }_{22}$ E. Mianowska, Strategie społecznego uczestnictwa młodzieży, Kraków 2008.
} 
ności siebie, poczuciem własnej podmiotowości i wpływu na bieg własnego życia, przekonaniem o potrzebie i słuszności uczenia się, jak również dobrą regulacją emocji mogącą mieć znaczenie w pokonywaniu trudności w uczeniu $\operatorname{się}^{23}$. Sumienność współwystępuje z podejmowaniem zobowiązań i identyfikacją z nimi, a więc z dwoma wymiarami tożsamości kształtującymi się we wkraczaniu $\mathrm{w}$ dorosłość ${ }^{24}$. Te z kolei współwystępują zawsze z podwyższonym poziomem orientacji tranzytywnej ${ }^{25}$.

W związku z tym, że osoby o silnej orientacji moratoryjnej deklarują poczucie bycia traktowanym przez nauczycieli przedmiotowo, a ponadto cechują się poczuciem bliskości rówieśników i silnej przynależności do grupy rówieśniczej ${ }^{26}$, co może je zniechęcać bądź odciągać od obowiązków związanych z uczeniem się, postawiono hipotezę o orientacji moratoryjnej jako orientacji osłabiającej zależność osiągnięć akademickich od sumienności.

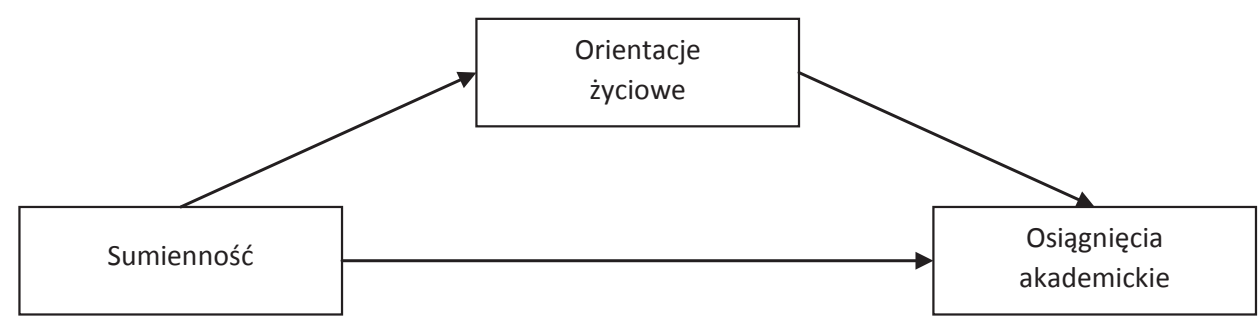

Ryc. 1. Hipotetyczne relacje między zmiennymi testowane w badaniu

\section{Metoda}

\section{Uczestnicy}

Badaniem objęto 111 studentów drugiego roku psychologii stacjonarnej, studiujących na Uniwersytecie im. Adama Mickiewicza w Poznaniu. Uczestnicy byli w wieku od 20 do 25 lat $(M=20,84 ; s d=1,02)$. Większość próby stanowiły kobiety $(n=93 ; 83,8 \%)$, co odzwierciedla rozkład płci na kierunku psychologia na tej uczelni.

${ }^{23}$ P. Jankowski, M. Rękosiewicz, Type of social participation and emotion regulation among upper secondary school students, Polish Psychological Bulletin, 2013, 44(3), s. 322-330.

${ }^{24}$ K. Luyckx, B. Soenens, L. Goossens, The personality-identity interplay in emerging adult women: convergent findings from complementary analysis, European Journal of Personality, 2006, 20, s. 195-215.

${ }^{25}$ M. Rękosiewicz, Type of social participation and identity formation, s. 277-287; taże, Społeczny kontekst ksztattowania się tożsamości.

${ }^{26}$ E. Mianowska, Strategie społecznego uczestnictwa. 


\section{Narzędzia badawcze}

Badanie testowe przeprowadzono za pomocą Kwestionariusza Partycypacji Społecznej (KPS-S2) badającego orientacje życiowe, oraz Inwentarza Osobowości NEO-FFI do badania cech osobowości ${ }^{27}$, a także metryczki w celu uzyskania informacji dotyczących wyników edukacyjnych studentów.

Kwestionariusz Partycypacji Społecznej (KPS), autorstwa Anny I. Brzezińskiej, Szymona Hejmanowskiego i Małgorzaty Rękosiewicz ${ }^{28}$, opiera się koncepcji partycypacji społecznej Reindersa i innych ${ }^{29}$. Zastosowana wersja narzędzia (KPS-S2) składa z 20 zdań oznajmujących tworzących dwie skale: orientacji tranzytywnej oraz orientacji moratoryjnej (po 10 pozycji w każdej skali). Każdemu zdaniu przyporządkowano pięć odpowiedzi: 1 - nie, 2 - raczej nie, 3 - trudno powiedzieć, 4 - raczej tak, 5 - tak. Wynikiem jest średnia punktów uzyskana w każdej z dwóch skal - minimalnie można uzyskać 1, a maksymalnie 5 punktów w każdej skali. Im wyższy wynik, tym wyższe natężenie orientacji. Rzetelność mierzona alfa-Cronbacha wyniosła w skali orientacji tranzytywnej 0,84, a w skali orientacji moratoryjnej - 0,71.

Inwentarz Osobowości NEO-FFI jest testem pozwalającym na wnioskowanie o natężeniu pięciu cech osobowości: neurotyczności, ekstrawersji, otwartości na doświadczenie, ugodowości i sumienności. Oryginalna wersja została stworzona przez Paula Costę i Roberta R. $\mathrm{McCrae}^{30}$, a w przeprowadzonym badaniu wykorzystano jej polską adaptację ${ }^{31}$. Arkusz składa się z 60 zdań oznajmujących (po 12 dla każdej z 5 skal). Każdemu zdaniu przyporządkowano pięć odpowiedzi: 1 - gdy się zdecydowanie nie zgadzasz lub gdy to stwierdzenie jest całkowicie nietrafne, 2 - gdy się zgadzasz lub gdy to stwierdzenie jest raczej nietrafne, 3 - gdy nie masz zdania lub nie możesz się zdecydować lub też to stwierdzenie jest równie trafne jak nietrafne, 4 - gdy się zgadzasz lub gdy to stwierdzenie jest raczej trafne, 5 - gdy się zdecydowanie zgadzasz lub gdy to stwierdzenie jest catkowicie trafne.

Wynik oblicza się sumując punkty uzyskane w każdej ze skal. Za każdą odpowiedź można uzyskać od 0 do 4 punktów. Wynik surowy każdej skali zawiera się w przedziale od 0 do 48 punktów. Im wyższy wynik, tym większe nasilenie danej cechy. Po obliczeniu wyników surowych dokonuje się przekształcenia na wyniki znormalizowane (steny). Rzetelność mierzona

${ }^{27}$ B. Zawadzki i in., Inwentarz Osobowości NEO-FFI Paula T. Costy Jr i Roberta R. McCrae. Adaptacja polska. Podręcznik, Warszawa 2010.

${ }^{28}$ M. Rękosiewicz, Kwestionariusz Partycypacji Społecznej (KPS): konstrukcja i analiza właściwości psychometrycznych, Studia Psychologiczne, 2013, 5, 3, s. 35-52.

${ }^{29}$ H. Reinders i in., Typologische Entwicklungswege Jugendlicher, s. 200-216; H. Reinders, P. Butz, Entwicklungswege Jugendlicher zwischen, s. 913-928.

${ }^{30}$ P.T. Costa, R.R. McCrae, Normal personality assessment in clinical practice: The NEO Personality Inventory, Psychological Assessment, 1992, 4(1), s. 5-13.

${ }_{31}$ B. Zawadzki i in., Inwentarz Osobowości NEO-FFI. 
alfa-Cronbacha wyniosła w skali neurotyczności - 0,86, ekstrawersji - 0,83, otwartości na doświadczenie - 0,68, ugodowości - 0,77, a sumienności - 0,86.

Metryczka, zastosowana na końcu badania, pozwoliła na uzyskanie informacji o płci, wieku oraz ocenach studentów z egzaminów z przedmiotów obligatoryjnych z poprzedzającego badanie semestru. Przedmioty te obejmowały: (1) Procesy poznawcze, (2) Psychologie rozwoju człowieka, (3) Psychologie społeczna, (4) Metodologię ze statystyką. W związku z dużą liczbą studentów, którzy powtarzali przedmiot Metodologia ze statystyka, uzyskali z niego zaliczenie warunkowe lub przepisanie oceny $\mathrm{z}$ innej uczelni, przedmiot ten został wykluczony z dalszych analiz. Obliczono średnią arytmetyczną z egzaminów $\mathrm{z}$ trzech pierwszych przedmiotów, a w dalszych analizach przekształcono ją w wynik standaryzowany.

\section{Procedura i analiza danych}

Przeprowadzono badanie grupowe w marcu 2018 roku, to jest na początku semestru letniego, który stanowił czwarty semestr studiów osób badanych. Badanie odbyło się w klasycznej formie papier-ołówek, po pierwszych organizacyjnych zajęciach $\mathrm{w}$ semestrze. Udział $\mathrm{w}$ badaniu zaproponowano wszystkim studentom z rocznika, a zgodę na udział wyraziło 111 studentów. Dane zostały opracowane w pakiecie IBM SPSS Statistics wersja 24.0.

\section{Wyniki}

W celu uzyskania odpowiedzi na pytanie o pośredniczącą rolę orientacji moratoryjnej i tranzytywnej na relację między cechami osobowości a osiągnięciami akademickimi studentów przeprowadzono analizę mediacji $w$ trzech krokach. W pierwszym kroku potwierdzono bezpośrednią zależność osiągnięć akademickich od jednej cechy osobowości, mianowicie sumienności (tab. 2). Model okazał się dobrze dopasowany do danych $[F(1,105)=12,79 ; p$ $\left.=0,01 ; R^{2}=0,11\right]$ i wskazywał, że im wyższy poziom sumienności studenta, tym lepsze jego osiągnięcia akademickie.

W kroku drugim testowano relację między zmienną niezależną (sumiennością) a mediatorem - orientacją moratoryjną, a także, niezależnie, między sumiennością a potencjalnym drugim mediatorem - orientacją tranzytywną. Każda z tych relacji okazała się istotna (tab. 3). Model z orientacją moratoryjną jako mediatorem okazał się dobrze dopasowany do danych $[F(1,109)$ $\left.=37,94 ; p<0,001 ; R^{2}=0,26\right]$ i wskazywał, że im wyższy poziom sumienności studenta, tym słabsze $\mathrm{u}$ niego zorientowanie moratoryjne. Model z orientacją tranzytywną jako mediatorem również okazał się dobrze dopasowany do 
danych $\left[F(1,109)=73,59 ; p<0,001 ; R^{2}=0,40\right]$ i wskazywał, odwrotnie niż w przypadku orientacji moratoryjnej - że im wyższy poziom sumienności studenta, tym silniejsze jego zorientowanie tranzytywne.

Tabela 2

Wyniki analizy regresji dla cech osobowości jako predyktorów osiągnięć akademickich

\begin{tabular}{|l|l|c|c|c|c|c|}
\hline & & \multicolumn{2}{|c|}{$\begin{array}{c}\text { Współczynniki } \\
\text { niestandaryzowane }\end{array}$} & \multicolumn{3}{|c|}{$\begin{array}{c}\text { Współczynniki } \\
\text { standaryzowane }\end{array}$} \\
\hline $\begin{array}{c}\text { Zmienna } \\
\text { zależna }\end{array}$ & $\begin{array}{c}\text { predyk- } \\
\text { tory }\end{array}$ & B & $\begin{array}{c}\text { błąd stan- } \\
\text { dardowy }\end{array}$ & $\beta$ & $t$ & $p$ \\
\hline $\begin{array}{l}\text { Osiągnię- } \\
\text { cia akade- } \\
\text { mickie }\end{array}$ & $\begin{array}{l}\text { neuro- } \\
\text { tyczność }\end{array}$ & $-0,04$ & 0,04 & $-0,09$ & $-0,87$ & 0,42 \\
\hline & $\begin{array}{l}\text { ekstra- } \\
\text { wersja }\end{array}$ & $-0,02$ & 0,05 & $-0,05$ & $-0,47$ & 0,64 \\
\hline $\begin{array}{l}\text { ntwartość } \\
\text { ś do- } \\
\text { nia }\end{array}$ & $-0,06$ & 0,06 & $-0,10$ & $-1,00$ & 0,32 \\
\hline & $\begin{array}{l}\text { ugodo- } \\
\text { wość }\end{array}$ & 0,01 & 0,04 & 0,03 & 0,27 & 0,78 \\
\hline & $\begin{array}{l}\text { sumien- } \\
\text { ność }\end{array}$ & 0,14 & 0,04 & 0,33 & 3,58 & 0,001 \\
\hline
\end{tabular}

Tabela 3

Wyniki analiz regresji dla sumienności jako predyktora orientacji życiowych

\begin{tabular}{|l|l|c|c|c|c|c|c|}
\hline & & \multicolumn{2}{|c|}{$\begin{array}{c}\text { Współczynniki } \\
\text { niestandaryzo- } \\
\text { wane }\end{array}$} & \multicolumn{3}{|c|}{$\begin{array}{c}\text { Współczynniki } \\
\text { standaryzowane }\end{array}$} & \\
\hline $\begin{array}{c}\text { Zmienna } \\
\text { zależna }\end{array}$ & $\begin{array}{c}\text { predyk- } \\
\text { tor }\end{array}$ & B & $\begin{array}{c}\text { błąd } \\
\text { stan- } \\
\text { dardo- } \\
\text { wy }\end{array}$ & $\beta$ & $t$ & $p$ & $R^{2}$ \\
\hline OM & $\begin{array}{l}\text { sumien- } \\
\text { ność }\end{array}$ & $-0,12$ & 0,02 & $-0,51$ & $-6,16$ & $<0,001$ & 0,26 \\
\hline OT & $\begin{array}{l}\text { sumien- } \\
\text { ność }\end{array}$ & 0,17 & 0,02 & 0,64 & 8,58 & $<0,001$ & 0,40 \\
\hline
\end{tabular}

OM - orientacja moratoryjna; OT - orientacja tranzytywna. 
W kroku trzecim, w modelach uwzględniono zarówno mediatory, jak i zmienną niezależną. $\mathrm{W}$ modelu uwzględniającym orientację moratoryjną i zmienną niezależną (sumienność), rola zmiennej niezależnej w przewidywaniu wyniku testu zmalała, choć nadal była istotna $(\beta=0,26 ; p=0,02)$. Mediator nie okazał się jednak istotnie powiązany ze zmienną zależną $(p=0,20)$. $\mathrm{W}$ modelu uwzględniającym orientację tranzytywną i sumienność mamy do czynienia $\mathrm{z}$ analogiczną sytuacją - rola zmiennej niezależnej $\mathrm{w}$ przewidywaniu wyniku testu nieco zmalała, pozostając nadal istotną $(\beta=0,30 ; p=$ $0,01)$, a mediator nie okazał się istotnie powiązany ze zmienną zależną $(p=$ 0,68). Tym samym, można skonkludować, że sumienność jest predyktorem zarówno osiągnięć akademickich, jak i orientacji życiowych studentów, ale orientacje te nie pośredniczą $\mathrm{w}$ relacji między sumiennością a osiągnięciami akademickimi.

\section{Dyskusja}

W przeprowadzonym badaniu udało się zreplikować wyniki innych badań wskazujących na sumienność jako predyktor wyników edukacyjnych studentów ${ }^{32}$. Im wyższy poziom sumienności u studentów, tym lepsze ich osiągnięcia akademickie, mierzone za pomocą średniej z egzaminów z przedmiotów obligatoryjnych. Potwierdzono więc, że studenci zorganizowani, wytrwali w działaniach edukacyjnych i zmotywowani do uczenia się, będą uzyskiwali lepsze stopnie. Wynik ten wydaje się zrozumiały nawet na poziomie zdroworozsądkowym.

Natomiast, przeciwnie do stawianych hipotez, orientacje życiowe okazały się nie mediować tego związku. Wykazano jedynie, że sumienność jest predyktorem orientacji tranzytywnej i moratoryjnej (im wyższa sumienność, tym silniejsza orientacja tranzytywna oraz tym słabsza orientacja moratoryjna), a wynik ten również stanowi replikację innych wyników ${ }^{33}$, co stanowi o wartości przeprowadzonego badania dla ogólnej wiedzy na temat psychologii rozwoju człowieka (ryc. 2).

Na podstawie takich cech studentów, jak ich wysoka obowiązkowość, dążenie do osiągnięć, samodyscyplina, rozwaga, skłonność do utrzymywania porządku czy kompetencja, możemy zatem przewidywać, że będą to osoby,

${ }^{32}$ M.C. O'Connor, S.V. Paunonen, Big Five personality predictors; A.E. Poropat, A meta-analysis of the five-factor model of personality, s. 971-990; tenże, The Eysenckian personality factors and their correlations, s. 41-58; tenże, A meta-analysis of adult-rated child personality, s. 239-252; S. Trapmann $\mathrm{i}$ in., Meta-analysis of the relationship between the Big Five, s. 132-151.

${ }_{33}$ M. Rękosiewicz, Osobowościowe predyktory orientacji życiowych studentów, Psychologia Rozwojowa (w druku). 
które traktują czas studiowania jako okres przygotowania do dorosłości - podejmują takie działania, które mają na celu nabycie umiejętności czy wiedzy niezbędnych w etapie rozwojowym, do którego wkraczają. Można również przewidywać, że będą to osoby, które w niewielkim stopniu będą traktować młodość jako czas przeznaczony jedynie na „korzystanie z możliwości” bez przygotowania do dorosłości. Dyscyplina w ogóle będzie się u nich więc ujawniała także w samodyscyplinie w przygotowaniu do dorosłości. Sumienność okazuje się więc cechą adaptacyjną i prorozwojową we wkraczaniu w dorosłość ${ }^{34}$.

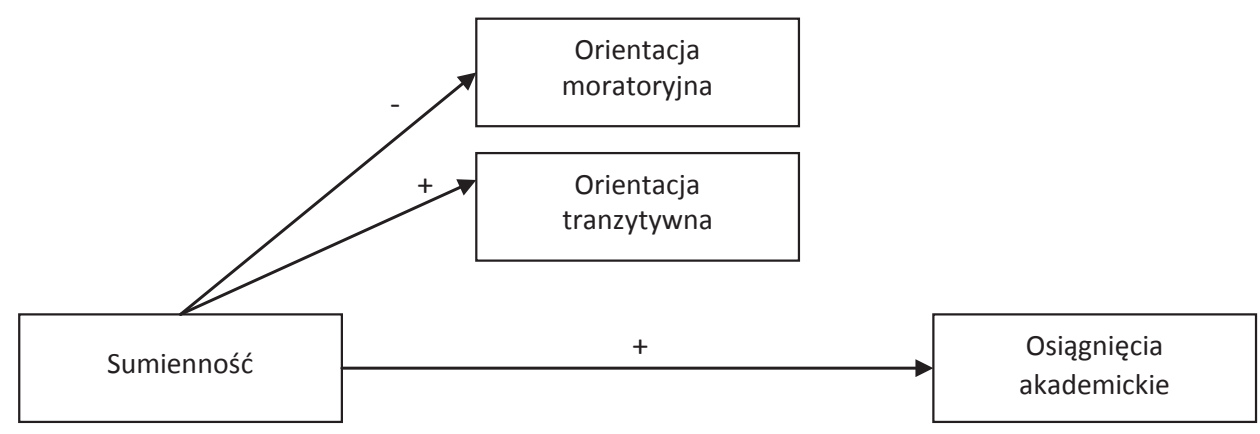

Ryc. 2. Sumienność jako predyktor orientacji życiowych i osiągnięć akademickich - wynik badania

Nie potwierdzono natomiast głównej hipotezy badawczej - orientacje życiowe nie mediują relacji między sumiennością a osiągnięciami akademic-

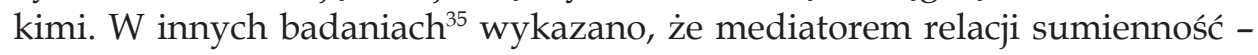
osiągnięcia akademickie jest takie podejście do uczenia się, w którym celem jest uczenie się samo w sobie lub cel stanowią dokonania. Być może więc wyjaśnienie wyników przeprowadzonego badania leży w zbyt szerokim charakterze orientacji życiowych, a mediatorami relacji między sumiennością a osiągnięciami są cechy węższe, bardziej ograniczone do samego procesu uczenia się. Obydwie orientacje życiowe odnoszą się co prawda specyficznie do sytuacji uczenia się i studiowania (przykładowa pozycja z KPS-S2: Do obowiązków związanych z uczeniem się podchodze poważnie, bo od tego zależy moja przyszłośc), ale także szeroko do funkcjonowania młodego człowieka (np. Korzystam z $\dot{z} y$ cia, póki jestem młoda). Ponadto, w postawionej hipotezie ukryte jest przekonanie o specyficznej dla studentów (osób wkraczających w dorosłość) roli orientacji życiowych w procesie uczenia się. Być może, w związku z tym, że

\footnotetext{
${ }^{34}$ Tamże.

${ }^{35}$ I. Sorić, Z. Penezić, I. Burić, The Big Five personality traits, goal orientations, s. 126-134.
} 
sumienność stanowi predyktor osiągnięć edukacyjnych na każdym szczeblu edukacyjnym, należy poszukiwać bardziej uniwersalnych dla wszystkich etapów rozwojowych mediatorów tej relacji.

Ważna wydaje się też kwestia samych „osiągnięć akademickich”. Jak wspomniano wcześniej, mierzy się je na dwa sposoby - tak jak w referowanym badaniu, to jest "obiektywnie”, a więc za pomocą wskaźników liczbowych - ocen, punktów procentowych uzyskanych w teście i tym podobnie oraz "subiektywnie", a więc poprzez badanie osobistej satysfakcji uczniów i studentów z własnych wyników (wtedy rola sumienności zanika, natomiast wzrasta rola neurotyczności - im niższy jej poziom, tym wyższa ocena własnych osiągnięćc ${ }^{36}$ ). W badaniu zdecydowano się na pierwsze rozwiązanie, ponieważ wydawało się, że uzyskiwanie jak najlepszych ocen, a przynajmniej zdawanie egzaminów jest swego rodzaju wypełnieniem oczekiwań społecznych stawianych przed wkraczającym w dorosłość człowiekiem. Można przypuszczać, że każde zdanie egzaminu i zdanie go jak najlepiej wskazuje o coraz lepszym przygotowaniu do dorosłości w sferze zawodowej (a więc także o zorientowaniu tranzytywnym). Uzyskane wyniki nie pozwalają jednak na podtrzymanie tego przypuszczenia. Być może zorientowanie tranzytywne w obszarze studiowania kryje się u studentów gdzieś indziej niż w ich ocenach - na przykład w subiektywnej ocenie poczucia bycia zadowolonym $\mathrm{z}$ uzyskiwanych kompetencji, $\mathrm{w}$ poczuciu samorozwoju, $\mathrm{w}$ poczuciu bycia coraz lepiej przygotowanym do uprawiania zawodu (co nie musi iść w parze z dobrymi ocenami z egzaminów). Niewykluczone także, że ukryte jest tu przekonanie studentów, że egzaminy w większej mierze sprawdzają wiedzę ogólną, a do przygotowania do pracy zawodowej (obszaru dorosłości) jest potrzebne ćwiczenie umiejętności praktycznych. Takie przypuszczenie wymaga dalszych badań.

Przeprowadzone badanie, mimo że o charakterze podstawowym, ma znaczenie dla praktyki psychologicznej i edukacyjnej. Ułatwia bowiem poszukiwanie "okrężnych dróg rozwoju" edukacyjnego - wskazuje, że ewentualne powodzenia i niepowodzenia akademickie mogą wynikać z pewnych stałych tendencji osobowościowych. Tendencje osobowościowe, podobnie jak poziom inteligencji u osób dorosłych, nie pozostawiają dużego pola do wprowadzania zmian. Możliwe jest jednak zadbanie o wspieranie rozwoju komponentów sumienności na wcześniejszych etapach rozwojowych i edukacyjnych tak, aby zadbać o powodzenie także w przyszłości, w czasie podejmowania studiowania oraz w czasie wkraczania w dorosłość.

Słabością przeprowadzonego badania jest, po pierwsze, ograniczenie do jednego kierunku studiów, co było konieczne ze względów metodologicznych (oceny z tych samych przedmiotów jako zmienne zależne). Wartościo-

\footnotetext{
${ }^{36}$ Por. S. Trapmann i in., Meta-analysis of the relationship between the Big Five.
} 
wa byłaby replikacja badania na innych kierunkach. Po drugie, badanie zostało przeprowadzone wśród studentów psychologii, a więc w grupie, w której zdecydowanie przeważają kobiety. Po trzecie, przeprowadzono je wśród studentów stacjonarnych, u których studiowanie stanowi podstawową aktywność. Aby dowiedzieć się, czy możliwe jest generalizowanie wyników na studentów w ogóle (a nie tylko stacjonarnych), należałoby także dokonać replikacji badania wśród studentów niestacjonarnych będących w podobnym wieku.

Dalsze badania empiryczne powinny przebiegać dwutorowo. Po pierwsze, w dalszym ciągu potrzebne są poszukiwania wyjaśnień mechanizmów oddziaływania cech osobowości na wyniki edukacyjne. Po drugie, wartościowe jest poszukiwanie możliwości wspierania rozwoju sumienności (determinowanej jedynie częściowo biologicznie, a w niemałej mierze społecznie - poprzez socjalizację i wychowanie) w celu wspierania wkraczania w dorosłość młodych ludzi oraz wspierania ich procesu edukacyjnego.

\section{BIBLIOGRAFIA}

Arnett J.J., Emerging adulthood. A theory of development from the late teens through the twenties, American Psychologist, 2000, 55.

Bidjerano T., Dai D.Y., The relationship between the big-five model of personality and self-regulated learning strategies, Learning and Individual Differences, 2007, 17(1).

Colman A.M., Stownik psychologii, Wydawnictwo Naukowe PWN, Warszawa 2009.

Costa P.T., McCrae R.R., Normal personality assessment in clinical practice: The NEO Personality Inventory, Psychological Assessment, 1992, 4(1).

Eysenck H.J. (red.), A model for intelligence, Springer Science \& Business Media, 2012.

Guntern S., Korpershoek H., van der Werf G., Benefits of personality characteristics and self-efficacy in the perceived academic achievement of medical students, Educational Psychology, 2017, 37(6).

Havighurst R.J., Developmental tasks and education, Longman, New York 1981.

Jankowski P., Rękosiewicz M., Type of social participation and emotion regulation among upper secondary school students, Polish Psychological Bulletin, 2013, 44(3).

Luyckx K., Soenens B., Goossens L. The personality-identity interplay in emerging adult women: convergent findings from complementary analysis, European Journal of Personality, 2006, 20.

Luyckx K., Schwartz S.J., Berzonsky M.D., Soenens B., Vansteenkiste M., Smits I., Goossens L., Capturing ruminative exploration: extending the four-dimensional model of identity formation in late adolescence, Journal of Research in Personality, 2008, 42.

McAdams D.P., Pals J.L., A new Big Five: Fundamental principles for an integrative science of personality, American Psychologist, 2006, 61(3).

Mianowska E., Strategie społecznego uczestnictwa młodzieży, Oficyna Wydawnicza Impuls, Kraków 2008.

Nguyen N.T., Allen L.C., Fraccastoro K., Personality predicts academic performance: Exploring the moderating role of gender, Journal of Higher Education Policy and Management, 2005, 27(1). 
O'Connor M.C., Paunonen S.V., Big Five personality predictors of post-secondary academic performance, Personality and Individual Differences, 2007, 43(5).

Perera H.N., McIlveen P., Oliver M.E., The mediating roles of coping and adjustment in the relationship between personality and academic achievement, British Journal of Educational Psychology, 2015, 85(3).

Pekrun R., Goetz T., Perry R.P., Kramer K., Hochstadt M., Molfenter S., Beyond test anxiety: Development and validation of the Test Emotions Questionnaire (TEQ), Anxiety, Stress and Coping, 2004, 17(3).

Poropat A.E., A meta-analysis of the five-factor model of personality and academic performance, Psychological Bulletin, 2009, 135(2).

Poropat A.E., The Eysenckian personality factors and their correlations with academic performance, British Journal of Educational Psychology, 2011, 81(1).

Poropat A.E., A meta-analysis of adult-rated child personality and academic performance in primary education, British Journal of Educational Psychology, 2014, 84(2).

Reinders H., Jugendtypen zwischen Bildung und Freizeit. Theoretische Präzisierung und empirische Prüfung einer differenziellen Theorie der Adoleszenz, Waxmann, Münster - New York - München - Berlin 2006.

Reinders H., Bergs-Winkels D., Butz P., Claßen G., Typologische Entwicklungswege Jugendlicher. Die horizontale Dimension sozialräumlicher Entfaltung, [w:] Zukunftsperspektiven Jugendlicher. Wirtschaftliche und soziale Entwicklungen als Herausforderung und Bedrohung für die Lebensplanung, red. J. Mansel, W. Schweins, M. Ulbrich-Herrmann, Juventa Verlag, München 2001.

Reinders H., Butz P., Entwicklungswege Jugendlicher zwischen Transition und Moratorium, Zeitschrift für Pädagogik, 2001, 47.

Rękosiewicz M., Kwestionariusz Partycypacji Społecznej (KPS): konstrukcja i analiza właściwości psychometrycznych, Studia Psychologiczne, 2013, 5, 3.

Rękosiewicz M., Type of social participation and identity formation in adolescence and emerging adulthood, Polish Psychological Bulletin, 2013, 44.

Rękosiewicz M., Społeczny kontekst kształtowania się tożsamości osób z niepetnosprawnościa intelektualną w okresie późnej adolescencji i wytaniającej się dorostości, rozprawa doktorska, 2016.

Rękosiewicz M., Osobowościowe predyktory orientacji życiowych studentów, Psychologia Rozwojowa (w druku).

Richardson M., Abraham C., Bond R., Psychological correlates of university students' academic performance: a systematic review and meta-analysis, Psychological Bulletin, 2012, 138(2).

Sorić I., Penezić Z., Burić I., The Big Five personality traits, goal orientations, and academic achievement, Learning and Individual Differences, 2017, 54.

Trapmann S., Hell B., Hirn J.O.W., Schuler H., Meta-analysis of the relationship between the Big Five and academic success at university, Zeitschrift für Psychologie/Journal of Psychology, 2007, 215(2).

Vermetten Y.J., Lodewijks H.G., Vermunt J.D., The Role of Personality Traits and Goal Orientations in Strategy Use, Contemporary Educational Psychology, 2001, 26(2).

Zawadzki B., Strelau J., Szczepaniak P., Śliwińska M., Inwentarz Osobowości NEO-FFI Paula T. Costy Jr i Roberta R. McCrae. Adaptacja polska. Podręcznik, Pracowania Testów Psychologicznych PTP, Warszawa 2010.

Zhou M., Moderating effect of self-determination in the relationship between Big Five personality and academic performance, Personality and Individual Differences, 2015, 86. 